\title{
Application of friction braking devices in drum shaft hoists
}

\author{
Tomasz Rokita \\ AGH University of Science and Technology, Poland
}

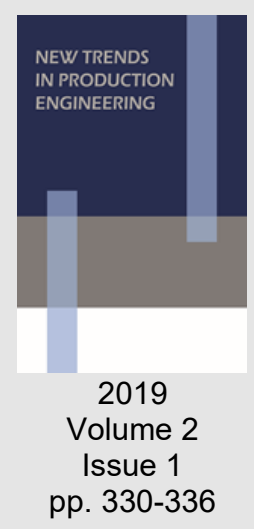

Date of submission to the Editor: 05/2019

Date of acceptance by the Editor: 07/2019

\section{INTRODUCTION}

The introduction in the eighties of the last century of friction braking devices to protect the movement of mining shaft hoists in Poland allowed to avoid disasters and serious failures caused by the crossing of extreme technological levels through the hoisting conveyances. Cases of final technological levels passing through the hoisting conveyances in Poland have also undeniably reduced the technical progress in the field of control and protection of the movement of mining hoists.

The brakes of the winding machine (acting on the drive pully) are one of the most reliable components of the mining shaft hoist. The question then arises as to whether it is worth applying so much weight to devices for emergency braking of conveyances.

In fact, end level crossings in the tower and the shaft shed are very unlikely, but they do happen and they always involve potential damage or even destruction of the mining shaft hoist (Wójcik 2002, Rokita, Wójcik 2015). The reasons for the majority of breakdowns occurring as a result of passing the extreme positions were the inattention of engine-drivers, inefficient systems controlling and securing the movement of the hoisting device, inefficient braking systems and rope slippage on the drive pully. In fact, only rope slippage on the drive pully causes total loss of control over the mining shaft hoist, or rather over the hoisting conveyances. This case occurs only in extracts with friction drives (often referred to as Koepe). In the case of drum drives, the situation of the slip of the rope can not take place. In Poland, the vast majority of mining shaft hoists have frictiontype drives (including all the most important shaft hoists). Drum-type lifts are usually less important or auxiliary, possibly emergency-revision. The abovementioned factors have meant that emergency braking systems so far have only been applied to friction hoists. However, in some countries, it is drum hoists that are the basic type of shaft lifts, and although to a lesser extent (than frictional extracts) they are also exposed to emergency level crossings. Hereinafter, the 
differences in the approach to solving the problem of emergency braking in both types of lifts are presented.

\section{THE PROBLEM OF EMERGENCY BRAKING IN FRICTION TYPE HOISTS}

The shaft hoist is a system of masses connected together, moving in a translational and rotational movement. The hoisting conveyances, the sections of hoist rope and balance ropes are moving, while the rotational motion is moved by the drive pulley, steering wheels, engine rotor, shafts connecting the rotor with the pulley or gears in the transmission, if equipped with a drive. The velocities of masses in translational and rotational motion are interdependent. The discussed hoist can be equipped with a machine driven by two motors (or one motor) of low-speed DC (usually) or alternating current (intermittently) connected by short rigid shafts with a pulley. On the driver pulley, the friction forces of the ropes against the liner balance the differences of forces in the ropes on both sides of the wheel. The drive pulley, through frictional engagement, is connected to the conveyances by means of branches of parallel carrying and balance ropes.

Thus, we are dealing here with a system consisting of a rotating part, which consists of solids with different moments of inertia connected by short fairly rigid shafts, and a moving part consisting of conveyances and sections of hoist rope and balance ropes of mass distributed in a manner continuous.

When starting calculations of the friction braking device, you should have the technical parameters (mass of lift elements, speed of movement, driving distance, etc.) and the diagram of the shaft hoist. First, the initial calculations are made using the simplest one-mass shaft hoist model. After the initial calculation of the braking device parameters, a variant simulation of the emergency braking process of the considered shaft hoist is carried out, using a discreet shaft hoist model. Both the calculation algorithm and the description of digital simulations performed are described in detail in (Wójcik 2002, Rokita 2017). These simulations take into account the operation of the safety brake of the winding machine and the drive torque of the drive motor atrophy. Obtaining the results of simulations in accordance with the assumptions allows to proceed with the design of the braking device.

In principle, two variants of the emergency braking system are assumed:

- braking both the conveyances passing the extreme technological level in the tower and the one that at the same time passes the extreme technological level in the shaft sump,

- braking only the conveyance passing the extreme technological level in the tower.

Fig. 1 schematically shows two variants of the emergency braking system used for the friction type lift. The first case when the braking of conveyance takes place simultaneously in the tower and sump of the shaft (Fig. 1a) was used as obligatory until the end of the $20^{\text {th }}$ century. The braking device in the tower was responsible for the destruction of most of the moving energy of the hoist masses. 


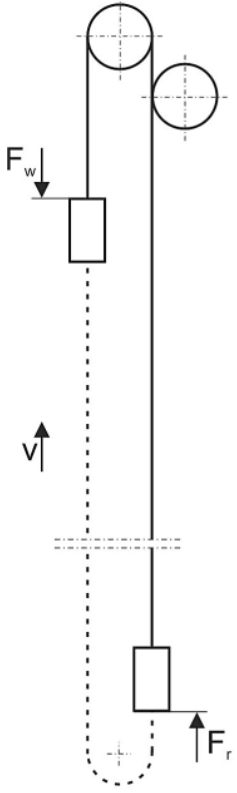

a)

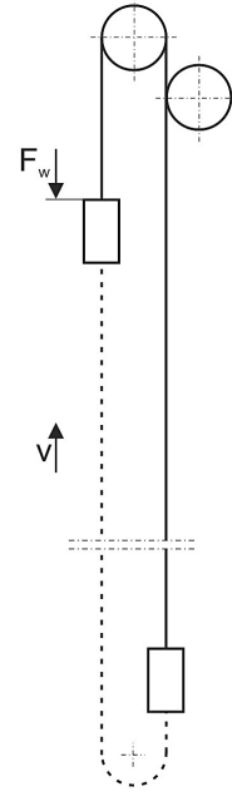

b)

Fig. 1 Scheme of Koepe hoist (with machine placed on the tower) with the arrangement of emergency braking systems

a) braking in the tower and sump shaft $\left.\left(F_{w}+F_{r}\right), b\right)$ braking in the tower only $\left(F_{w}\right)$

The braking device in the sump was usually responsible for cutting only $20-30 \%$ of the energy of the hoist.

An important stage in solving the problem of emergency braking was the development of devices that capture the conveyances. Thanks to these devices, from the beginning of emergency braking the conveyance remains locked with brakes, so that after stopping at possible breaking of hoist ropes hang on the structure fixing the friction braking system. After the kinetic energy is lost, the extraction device will stop and the catches of the conveyance will hang on the pins of the collecting device. The frictional forces occurring between friction brakes and braking slats transfer completely the load from the spoil conveyance and the balance rope to the tower guide stem.

Developed at the AGH University of Science and Technology in Kraków and testing in mine conditions the devices that capture the extraction conveyances, which in combination with friction braking devices form the so-called movable fender beams enabled the introduction of appropriate provisions in mining regulations (Regulation 2002, Annex No. 4. 2002). According to these records, it was possible to use only one emergency braking system in the shaft hoist (provided that it has the capability of capturing the extraction conveyances) installed in the shaft tower and is able to completely destroy the kinetic energy of the hosit. The braking force applied to the tower conveyance is transferred through the support line to the conveyance located in the shaft sump. In this way, the braking system in the tower ensures that both extraction conveyances are stopped. This approach eliminated the need for building and burdensome control of braking systems in the shaft sump. The solution of this type is shown schematically in Fig. 1b, it was used in a dozen or so wells mainly in KGHM Polska Miedź S.A. 


\section{EMERGENCY BRAKING PROBLEM IN DRUM TYPE HOISTS}

A slightly different situation occurs in the case of emergency braking of the extraction conveyances in the drum hoist. In this case, one conveyances is being hung at the end of the rope, which once is in the headroom and once the shaft (Fig. 2). There is therefore no possibility to use only one emergency braking system.

a)

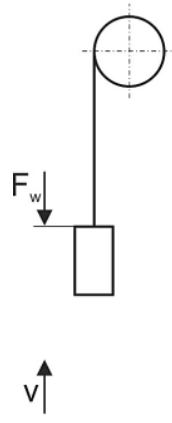

b)

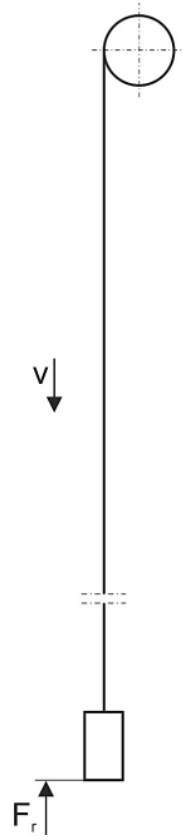

c)

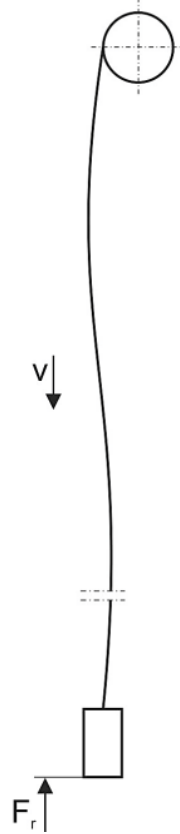

Fig. 2 Scheme for the drum hoist (with the machine placed on the tower) with the arrangement of emergency braking systems a) braking in the shaft tower $\left(F_{w}\right)$, b) braking the shaft's shaft $\left(F_{r}\right)$, c) relieving the hoist rope during the braking of the conveyance in the shaft sump

Two braking systems designed to operate independently of each other must be provided. The braking system in the tower (for the case shown in Fig. 2a) is designed to destroy the kinetic energy of not only the braked conveyance, but also the energy of the rotating drum (with the hoist rope wound on it) and the rotor of the propulsion engine. The braking system in the sump is designed to stop only the conveyance moving down. There is no question of any impact on the brake drum of the braking system in the sump, the hoist rope unwinding from the drum also can not be taken into account (the loosened rope can not "push" the conveyance) Fig. 2c.

\section{AN EXAMPLE OF USING EMERGENCY BRAKING DEVICES IN A DRUM HOIST \\ Parameters of the shaft hoist}

The next section presents the solutions of friction emergency braking systems for a drum hoist with a cage with a lifting capacity of $3000 \mathrm{~kg}$. The conveyance travel speed is $9 \mathrm{~m} / \mathrm{s}$, the driving path in the shaft is $1000 \mathrm{~m}$ and the diameter of the pulley rpm $3.5 \mathrm{~m}$. Calculations of the emergency braking process for the selected braking force of the friction device in accordance with the algorithm found in (Hansel, Wójcik, Rokita 2002). 


\section{Braking the cage in the tower}

In order to decelerate the mass in the tower, it was assumed that the cage would be braked with 4 friction brakes with a braking force of $60 \mathrm{kN}$ each. The total braking force of the brake assembly is $F_{w}=4 \times 60 \mathrm{kN}=240 \mathrm{kN}$. Fig. 3 contains a diagram of calculations for braking a tower cage.

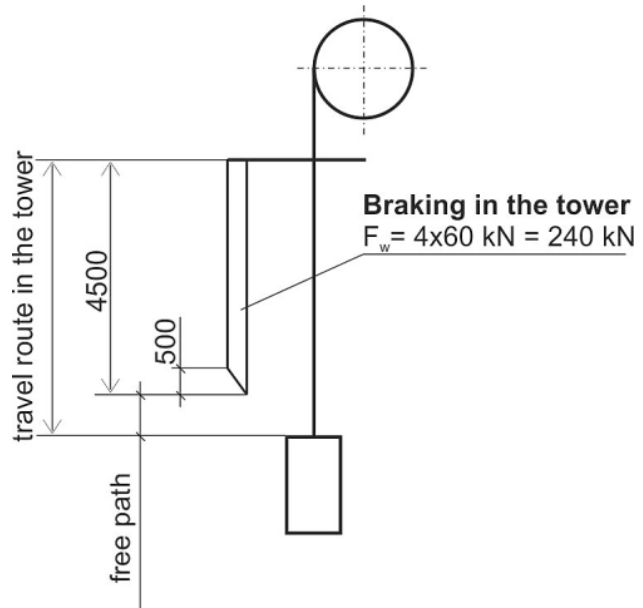

Fig. 3 Scheme of calculations of braking of a cage in a tower

The calculations of the emergency braking process indicated that four frictional brakes in the form of movable fender beams ensure full loss of the nominal value of the kinetic energy of the masses of the mining hoist. The results of calculations are summarized in Table 1.

Table 1 List of calculation results for the cage braked in the tower

\begin{tabular}{l|l|c|c|c|}
\hline \multicolumn{1}{|c|}{ Traffic case } & $\begin{array}{c}\text { Deceleration } \\
{\left[\mathbf{m} / \mathbf{s}^{2}\right]}\end{array}$ & $\begin{array}{c}\text { Braking } \\
\text { performance [\%] }\end{array}$ & $\begin{array}{c}\text { Braking } \\
\text { distance [m] }\end{array}$ & $\begin{array}{c}\text { Coefficient } \\
\text { „K” }\end{array}$ \\
\hline Driving with an empty cage up & 9.688 & 103,3 & 4.364 & 0.232 \\
\hline Driving with full frame up & 9.699 & 102.7 & 4,387 & 0.232 \\
\hline * The ratio of forces in the hoist ropes above the conveyance braked in the tower to the calculated breaking \\
force of the rope.
\end{tabular}

\section{Braking the cage in the sump}

To stop the masses in the sump, it was assumed that the cage would be braked in two levels.

I braking level. On the first level braking will take place using 4 friction brakes with a braking force of $24.5 \mathrm{kN}$ each. The total braking force of the brake assembly is $F_{r 1}=4 \times 24.5 \mathrm{kN}=98 \mathrm{kN}$. Fig. 4 contains a diagram of calculations for braking a cage in a tower. The results of calculations are presented in Table 2.

At the first level of braking, it is not possible to dissipate all the kinetic energy of the moving masses for the case of leaving the full frame. When traveling with the full cage down after passing the first level of braking $(4.5 \mathrm{~m}), 253 \mathrm{~kJ}$ of energy will remain to be dissipate, which corresponds to the conveyance speed of 7.9 $\mathrm{m} / \mathrm{s}$.

On the 2nd level, braking will take place using 4 friction brakes with a braking force of $15 \mathrm{kN}$ each. 


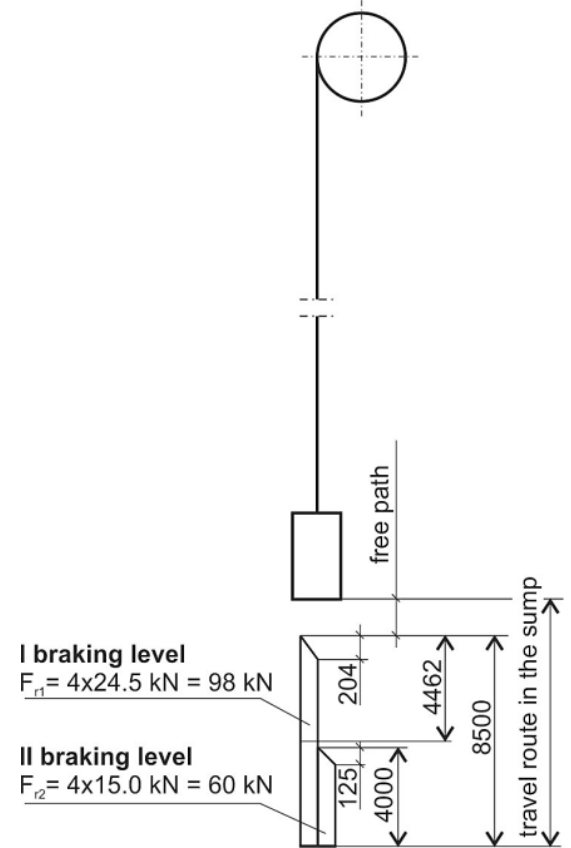

Fig. 4 Scheme for calculating the braking of the cage in the sump

Table 2 List of calculation results for the cage braked in the sump on level I (4.5 $\mathrm{m}$ braking)

\begin{tabular}{|l|c|c|c|}
\hline \multicolumn{1}{|c|}{ Traffic case } & $\begin{array}{c}\text { Deceleration } \\
{\left[\mathrm{m} / \mathbf{s}^{2}\right]}\end{array}$ & $\begin{array}{c}\text { Braking } \\
\text { performance [\%] }\end{array}$ & $\begin{array}{c}\text { Braking } \\
\text { distance [m] }\end{array}$ \\
\hline Driving with an empty cage down & 9.519 & 100 & 4.462 \\
\hline Driving with full frame down & 2.334 & 22.8 & 4.5 \\
\hline
\end{tabular}

The total braking force of the brake assembly is $F_{\mathrm{cr} 2}=4 \times 15 \mathrm{kN}=60 \mathrm{kN}$. Braking on the second level will start after driving through the cage $4.5 \mathrm{~m}$ from the beginning of braking on 1st level.

Such arrangement of brakes will ensure full braking of the cage with a downward load with a deceleration of $9.77 \mathrm{~m} / \mathrm{s}^{2}$ on the $7.76 \mathrm{~m}$ path. Fig. 5 shows a diagram of the location of friction brakes in the sump of the cage drum hoist.

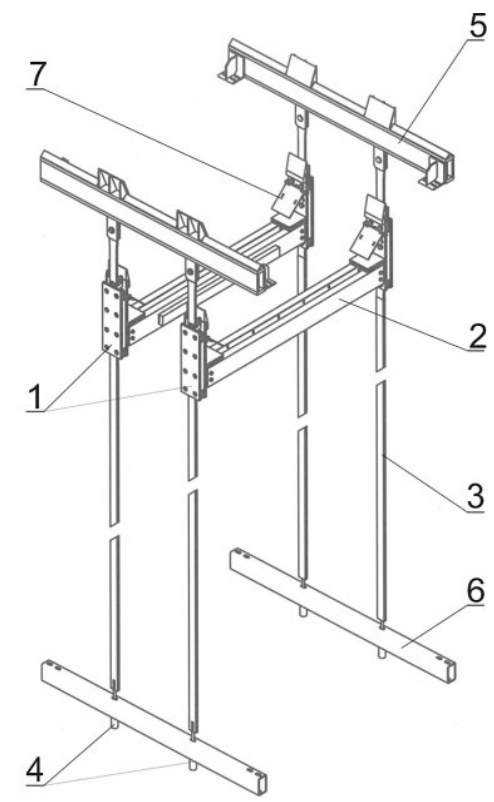

Fig. 5 Scheme of the location of friction brakes in the shaft sump 1 - friction brake bodies, 2 - movable fender beams, 3 - brake bars, 4 - tensioning bolts of brake bars, 5 - upper batten fastening beams, 6 - lower batten fixing beams, 7 - brake covers 
During braking at any load on the cage, the braking deceleration will not exceed $9.81 \mathrm{~m} / \mathrm{s}^{2}$, which is a prerequisite when driving people.

The solution described in this article will be the first application of friction braking devices and movable fender beams in a drum type mining shaft hoist.

\section{REFERENCES}

Wójcik M. (2002) Awaryjne hamowanie górniczych wyciągów szybowych urządzeniami ciernymi - teoria, badania i aplikacje przemysłowe", Studia Rozprawy Monografie Wydawnictwo Instytutu Gospodarki Surowcami Mineralnymi i Energią PAN Kraków.

Rokita T., Wójcik M. (2015) Emergency braking of mine shaft hoists applying friction arresting devices - theory, tests and industrial applications, „Hoist \& Haul” Proceedings of the International Conference on Hoisting and Haulage, Edited by Borje Johansson, SME, Stockholm Sweden s. 291-300.

Rokita T. (2017) Poprawa bezpieczeństwa górniczych wyciągów szybowych poprzez zastosowanie ciernych urządzeń hamujących" Bezpieczeństwo Pracy i Ochrona Środowiska w Górnictwie; nr 6, s. 9-16.

Rozporządzenie Ministra Gospodarki z dnia 28 czerwca 2002 r. w sprawie bezpieczeństwa i higieny pracy, prowadzenia ruchu oraz specjalistycznego zabezpieczenia przeciwpożarowego w podziemnych zakładach górniczych (Dz. U. Nr 139, poz. 1169 oraz z 2006 r. Nr 124, poz. 863 oraz z 2010 r. Nr 126, poz. 855).

Załącznik $\mathrm{Nr} 4$ „Szczegółowe zasady prowadzenia ruchu w wyrobiskach” do Rozporządzenia Ministra Gospodarki z dnia 28 czerwca 2002 r. w sprawie bezpieczeństwa i higieny pracy, prowadzenia ruchu oraz specjalistycznego zabezpieczenia przeciwpożarowego w podziemnych zakładach górniczych.

Hansel J., Wójcik M., Rokita T. (2002) Metoda obliczania ruchomych belek odbojowych współpracujących z ciernymi układami do awaryjnego hamowania naczyń wyciągowych. Umowa licencyjna nr 12/2002 - RN-WUL-60/2000, Rozwiązania stanowiące tajemnice Akademii Górniczo-Hutniczej w Krakowie typu „Knowhow".

\footnotetext{
Abstract.

This article presents the problem of emergency braking in mining shaft hoists equipped with drum. The industrial applications of friction devices and mobile fender beams concerned only friction shaft hoists. For drum devices, it is necessary to use braking devices both in the shaft tower and its sump. The impact of such a solution on the construction of braking devices and on the braking process itself is the subject of the paper.
}

Keywords: shaft hoists, emergency braking, mobile fender beams 